\title{
当科に打ける気管食道シャント閉鎖術症例の検討
}

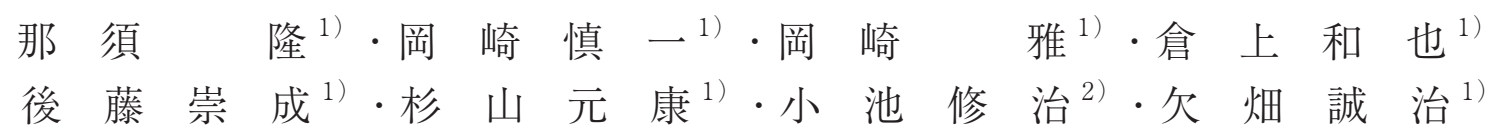

\section{Clinical Investigation of Surgical Closure of Tracheoesophageal Shunt}

\author{
Takashi Nasu' ${ }^{1)}$, Shinichi Okazaki ${ }^{1)}$, Masashi Okazaki ${ }^{1)}$, Kazuya Kurakami ${ }^{1)}$ \\ Takanari Goto ${ }^{1)}$, Motoyasu Sugiyama ${ }^{1)}$, Syuji Koike ${ }^{2)}$ and Seiji Kakehata ${ }^{1)}$
}

The purpose of this study was to elucidate the appropriate time for closing a tracheoesophageal shunt for a safe and non-invasive surgical procedure, after acquiring another type of vocal rehabilitation. A tracheoesophageal shunt is globally considered to be the most useful tool for excellent vocal rehabilitation; nevertheless, it must be closed for several reasons. In some cases, surgical closure of a tracheoesophageal shunt is difficult due to poor histological conditions around the shunt. We herein propose a new strategy of vocal rehabilitation to utilize a tracheoesophageal shunt effectively.

Materials and methods: Between 1995 and 2014, 46 patients underwent voice prosthesis insertion surgery. Nine (eight laryngeal cancer patients, one thyroid cancer patient) of these patients underwent surgical closure of a tracheoesophageal shunt. We investigated their cancer treatments, reasons for closing the tracheoesophageal shunt, period of voice prosthesis insertion, operative method, number of operations, and outcome.

Results: The reasons for closing the tracheoesophageal shunt were aspiration pneumonia and acquisition of esophageal voice in 4 patients each. Regarding the period of voice prosthesis speech, 6 patients had used it for approximately 3 years and 3 patients for more than 7 years. Approximately all 3 -year users underwent a non-invasive surgical procedure, such as triple-layered suture, and their operation succeeded the first time. Conversely, the more than 7 -year users required an invasive surgical procedure, such as a pedicle flap, and had to undergo more than one operation.

Conclusion: In the present study, tracheoesophageal shunt closure could be performed within 3 years via a safe and non-invasive surgical procedure. We recommend that the operation for a tracheoesophageal shunt be undertaken at a relatively early stage after total laryngectomy. Such patients should acquire esophageal voice within 3 years and undergo surgical closure of the tracheoesophageal shunt as soon as possible.

Key words : tracheoesophageal shunt, surgical closure, esophageal voice, aspiration pneumonia

\section{はじめに}

気管食道シャント（以下 TEシャント）は，他の代用音 声と比較して, 音声習得率が高く ${ }^{1 \sim 6)}$ 習得に要する期間が 短いこと，自然な音声が得られることから，代替音声の “GOLD STANDARD”と評されている ${ }^{7)}$. 一方，TEシャ ントに関連した合併症や，TEシャント発声の必要がなく なったとして，シャント孔を閉鎖する症例も少なからず存 在する。また閉鎖手術を行う際， $\mathrm{TE}$ シャント周囲の不良 な組織環境により閉鎖が困難な症例も経験する。今回, 我々は，TEシャント閉鎖術を実施した症例について，症 例の臨床的背景，閉鎖に至った理由，シャント閉鎖の術式 などを検討し，TEシャントを有効に使用するため適切な 代替音声獲得の手順について考察した。

\section{対象と方 法}

当科で，単純喉頭全摘術後にTEシャントを造設した症 例で，シャント閉鎖手術を施行した9例を対象とした。男 性 8 例, 女性 1 例で, 年齢は 59 歳から 73 歳（中央值 69 歳)，閉鎖に至るまでの期間は 18 ケ月か 194 ケ (中央 值 33 ヶ月) であった。疾患の内訳は喉頭癌 8 例，甲状腺癌 1 例であった。

当科に打ける TEシャント造設は, 1999 年から 2012 年 までの単純喉頭全摘術症例には, 原則, 一期的に施行した。 1999 年以前に単純喉頭全摘術を施行した症例では，希望 者にのみ二期的な造設術を行った。遊離空腸や遊離皮弁再 建，胃管再建を伴う症例には，原則的にTEシャント造設 は行っていない. TEシャントを積極的に造設していない

1) 山形大学医学部耳鼻咽喉・頭頸部外科学講座

2) 山形県立中央病院耳鼻咽喉科

1) Department of Otolaryngology-Head and Neck Surgery, Yamagata University School of Medicine

2) Department of Otolaryngology-Head and Neck Surgery, Yamagata Prefectural Central Hospital 
期間も含め, 当科では喉頭摘出者団体に積極的に関わって 食道発声の習得を促すなどの対応は行っていなかった。な お，ボイスプロステーシスの交換頻度は，トラブルがなけ れば，少なくとも 4〜5ヶ月に一度は交換することとした．

当科で施行したTEシャント閉鎖術は，以下の 3 つ術式 に大別される。

(1) 3 創縫合（図 1) TEシャント孔を新鮮化し，食道は Albert- Lembert縫合し,さらに気管膜様部を縫合す る.

(2) TEシャント気管輪摘出・食道 2 創縫合・気管孔再建 (図 2): 気管孔を全周切開し，気管孔以下の気管壁を 全周剥離展開し，TEシャント挿入膜様部がある気管 輪を 1 リング切除する。食道シャント孔を AlbertLembert縫合したのち，新たに気管孔を形成する。

(3) TEシャント気管輪摘出・食道 2 創縫合・大胸筋弁と DP 皮弁による前頸部再建・気管孔再建（図 3)：上記 (2)術式を施行する過程で，血行不良の前頸部皮膚を 合併切除し, 食道シャント部縫合面を血流のよい大 胸筋弁で被覆した後, 前頸部皮膚はDP皮弁で再建 し，新たに気管孔を形成する。

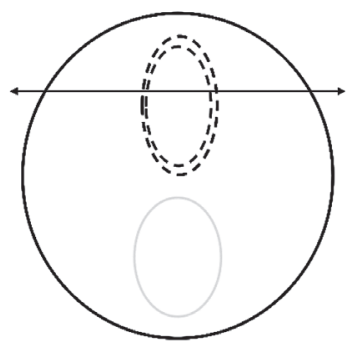

A

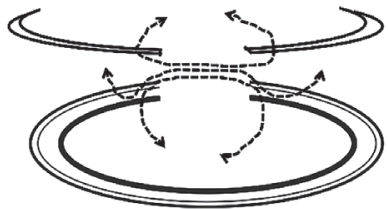

B
図 13 層縫合 手術シェーマ

$\mathrm{A}$ ：気管孔正面.上段破線楕円は TEシャント孔

B：図 A 矢印 $(\leftrightarrow)$ レベルの軸位断像. 上段は気管孔,

下段は食道. 破線は縫合ルート

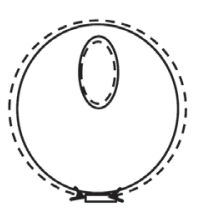

A

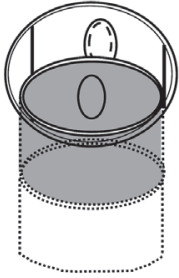

B

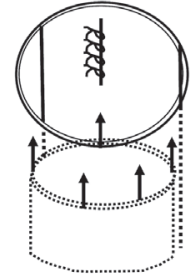

C

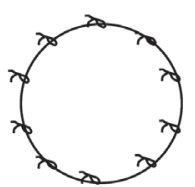

D
図 $2 \mathrm{TE}$ シャント気管輪摘出・食道 2 創綘合・気管孔再建 手 術シェーマ

A：気管孔正面. 矢印破線 $(\leftrightarrow)$ は気管孔周囲の皮切ラ イン。破線楕円はTEシャント孔

$\mathrm{B}$ ：気管壁全周剥離後. グレー円筒は切除する気管輪.

C：食道側シャント孔縫合と気管孔作成

D：完成した気管孔
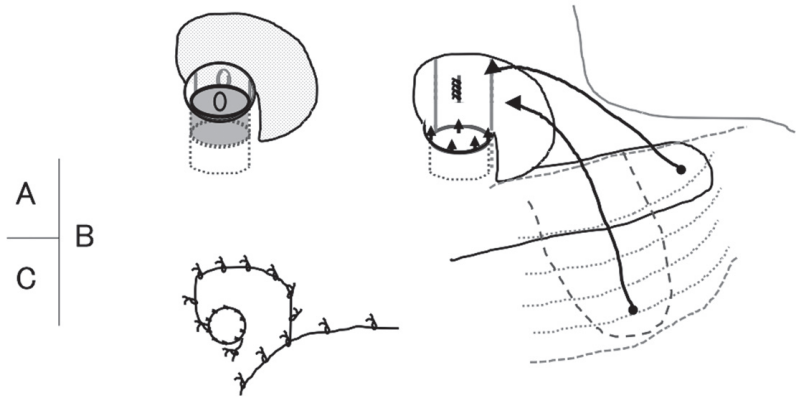

図 3 TE シャント気管輪摘出・食道 2 創縫合 · 大胸筋弁と DP 皮弁による前頸部再建・気管孔再建 手術シェーマ

$\mathrm{A}$ ：気管壁全周剥離後. グレー円筒は切除する気管輪. 気管孔上方のグレードットパターン領域は皮膚切除 部位

B：食道側シャント孔縫合. DP皮弁, 大胸筋弁作成・ 移動

C : 完成した気管孔

閉鎖術を行う際，基本的には簡便な術式から行ったが， 創離開があった際には，術式(2)や(3)を行った。

今回の検討では，最初に，当科における TEシャント症 例の全体像を確認するため, 1995 年から 2014 年までの 20 年間における単純喉頭全摘症例における TEシャント造 設症例の割合とその転帰を確認した。次に, 原発巣治療の 背景因子として, 年齢, 性, 原発巣 (亜部位), 一次治療 か否か, TNM分類, 照射線量, 化学療法, 治療後観察期間, 転帰を検討した。また, シャント閉鎖術の背景因子として, シャント造設時期 (一期再建か否か), 閉鎖の理由, シャ ント閉鎖までの期間, 閉鎖術式, 閉鎖に要した手術回数, 閉鎖に関した転帰を検討した。

\section{結果}

1) 過去 20 年間の単純喉頭全摘症例におけるTEシャント 造設症例の割合とその転帰

1995 年から 2014 年までの当科に打ける単純喉頭全摘症 例におけるTEシャント造設症例の割合とその転帰を図 4 に示した. TEシャントは, 全体の $72 \%$ に実施されていた。

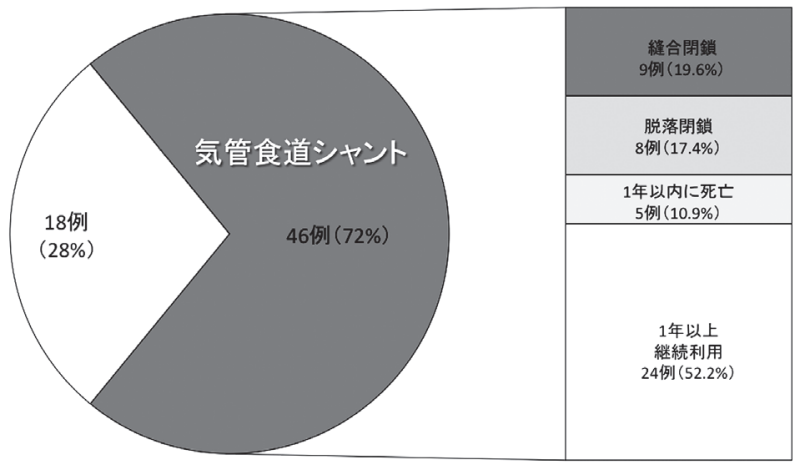

図 4 単純喉頭摘出症例における気管食道シャントの割合と転帰 （1995-2014 年 単純喉頭摘出症例：64 例） 
表 1 シャント閉鎖手術症例の背景 (原発巣治療)

\begin{tabular}{|c|c|c|c|c|c|c|c|c|}
\hline & $\begin{array}{c}\text { 年齢 } \\
\text { 性 }\end{array}$ & $\begin{array}{c}\text { 亜部位 } \\
\text { 病理 }\end{array}$ & 治療 & TNM & 照射線量 & 化学療法 & $\begin{array}{c}\text { 観察期間 } \\
\text { (年) }\end{array}$ & 転帰 \\
\hline 1 & $\begin{array}{c}68 \text { 歳 } \\
\text { 男 }\end{array}$ & $\begin{array}{l}\text { 声門下 } \\
\text { SCC }\end{array}$ & 一次治療 & T4aNOMO & $\begin{array}{c}46 \\
\text { 術後 }\end{array}$ & & 18 & 無病生存 \\
\hline 2 & $\begin{array}{c}\text { 68歳 } \\
\text { 男 }\end{array}$ & $\begin{array}{l}\text { 声門上 } \\
\text { SCC }\end{array}$ & 一次治療 & T2N2aM0 & $\begin{array}{c}70 \\
\text { 術前·後 }\end{array}$ & $\begin{array}{l}\text { 同時併用 } \\
\text { (CBDCA) }\end{array}$ & 14 & 他病死 \\
\hline 3 & $\begin{array}{c}\text { 63歳 } \\
\text { 男 }\end{array}$ & $\begin{array}{l}\text { 声門上 } \\
\text { SCC }\end{array}$ & 一次治療 & T3NOMO & $\begin{array}{c}40 \\
\text { 術前 }\end{array}$ & $\begin{array}{l}\text { 同時併用 } \\
\text { (CBDCA) }\end{array}$ & 16 & 他病死 \\
\hline 4 & $\begin{array}{c}56 \text { 歳 } \\
\text { 男 }\end{array}$ & $\begin{array}{c}\text { 声門上 } \\
\text { SCC }\end{array}$ & 再発治療 & rT2NOMO & $\begin{array}{c}70 \\
\text { 一次治療 }\end{array}$ & $\begin{array}{l}\text { 同時併用 } \\
\text { (CBDCA) }\end{array}$ & 15 & 無病生存 \\
\hline 5 & $\begin{array}{c}\text { 61歳 } \\
\text { 男 }\end{array}$ & $\begin{array}{c}\text { 声門上 } \\
\text { SCC }\end{array}$ & 一次治療 & T3N0M0 & & & 13 & 無病生存 \\
\hline 6 & $\begin{array}{c}67 \text { 歳 } \\
\text { 男 }\end{array}$ & $\begin{array}{l}\text { 声門上 } \\
\text { SCC }\end{array}$ & 再発治療 & rT3NOMO & $\begin{array}{c}66 \\
\text { 一次治療 }\end{array}$ & $\begin{array}{c}\text { 同時併用 } \\
\text { (TAX) }\end{array}$ & 10 & 無病生存 \\
\hline 7 & $\begin{array}{c}66 \text { 歳 } \\
\text { 男 }\end{array}$ & $\begin{array}{l}\text { 声門上 } \\
\text { SCC }\end{array}$ & 一次治療 & T3NOMO & $\begin{array}{c}44 \\
\text { 術後 }\end{array}$ & & 8 & 他病死 \\
\hline 8 & $\begin{array}{c}58 \text { 歳 } \\
\text { 男 }\end{array}$ & $\begin{array}{c}\text { 声門上 } \\
\text { SCC }\end{array}$ & 一次治療 & T3N0M0 & & & 6 & 無病生存 \\
\hline 9 & $\begin{array}{c}63 \text { 歳 } \\
\text { 女 }\end{array}$ & $\begin{array}{l}\text { 甲状腺 } \\
\text { 乳頭癌 }\end{array}$ & 一次治療 & T4aNOMO & & & 6 & 無病生存 \\
\hline
\end{tabular}

表 2 シャント閉鎖手術症例の背景 (気管食道シャント)

\begin{tabular}{|c|c|c|c|c|c|c|c|}
\hline & $\begin{array}{c}\text { 年齢 } \\
\text { 性 }\end{array}$ & $\begin{array}{l}\text { シャント造 } \\
\text { 設 }\end{array}$ & 閉鎖に至った理由 & $\begin{array}{c}\text { シャント閉鎖 } \\
\text { までの期間(月) }\end{array}$ & 閉鎖手術術式 & $\begin{array}{l}\text { 手術 } \\
\text { 回数 }\end{array}$ & 転帰 \\
\hline 1 & $\begin{array}{c}\text { 85歳 } \\
\text { 男 }\end{array}$ & II 期 & $\begin{array}{c}\text { シャント孔よりリーク } \\
\text { 嚥下性肺炎 }\end{array}$ & 194 & 3層縫合 & 1 & $\begin{array}{l}\text { 閉鎖 } \\
\text { できず }\end{array}$ \\
\hline 2 & $\begin{array}{c}\text { 75歳 } \\
\text { 男 }\end{array}$ & I 期 & $\begin{array}{c}\text { シャント孔よりリーク } \\
\text { 嚥下性肺炎 }\end{array}$ & 84 & $\begin{array}{c}\text { 気管孔新鮮化 } \\
\text { 食道2層縫合 } \\
\text { 大胸筋弁·DP皮弁 }\end{array}$ & 4 & 閉鎖 \\
\hline 3 & $\begin{array}{c}\text { 65歳 } \\
\text { 男 }\end{array}$ & I 期 & $\begin{array}{l}\text { 発声不能. } \\
\text { 気管孔狭窄 }\end{array}$ & 30 & $\begin{array}{l}\text { 気管孔新鮮化 } \\
\text { 食道2層縫合 }\end{array}$ & 1 & 閉鎖 \\
\hline 4 & $\begin{array}{c}59 \text { 歳 } \\
\text { 男 }\end{array}$ & I 期 & $\begin{array}{l}\text { シャント発声不用 } \\
\text { (食道発声可能) }\end{array}$ & 29 & 3層縫合 & 1 & 閉鎖 \\
\hline 5 & $\begin{array}{c}\text { 62歳 } \\
\text { 男 }\end{array}$ & I 期 & $\begin{array}{l}\text { シャント発声不用 } \\
\text { (食道発声可能) }\end{array}$ & 24 & 3層縫合 & 1 & 閉鎖 \\
\hline 6 & $\begin{array}{c}68 \text { 歳 } \\
\text { 男 }\end{array}$ & I 期 & $\begin{array}{c}\text { シャント孔よりリーク } \\
\text { 嶼下性肺炎 }\end{array}$ & 18 & 3層縫合 & 1 & 閉鎖 \\
\hline 7 & $\begin{array}{c}\text { 73歳 } \\
\text { 男 }\end{array}$ & I 期 & $\begin{array}{c}\text { シャント孔よりリーク } \\
\text { 嚥下性肺炎 }\end{array}$ & 87 & $\begin{array}{c}\text { 気管孔新鮮化 } \\
\text { 食道2層縫合 } \\
\text { 大胸筋弁·DP皮弁 }\end{array}$ & 2 & 閉鎖 \\
\hline 8 & $\begin{array}{c}61 \text { 歳 } \\
\text { 男 }\end{array}$ & I 期 & $\begin{array}{l}\text { シャント発声不用 } \\
\text { （食道発声可能） }\end{array}$ & 39 & $\begin{array}{l}\text { 気管孔新鮮化 } \\
\text { 食道2層縫合 }\end{array}$ & 1 & 閉鎖 \\
\hline 9 & $\begin{array}{c}\text { 65歳 } \\
\text { 女 }\end{array}$ & I 期 & $\begin{array}{l}\text { シャント発声不用 } \\
\text { (食道発声可能) }\end{array}$ & 33 & $\begin{array}{l}\text { 気管孔新鮮化 } \\
\text { 食道2層縫合 }\end{array}$ & 1 & 閉鎖 \\
\hline
\end{tabular}


本検討の対象は 9 例で全体の約 2 割を占めた。他に経過観 察中に脱落し，以後再挿入を必要としなかった症例は 8 例 であり，閉鎖術を施行した症例とほぼ同等の症例数であっ た。またTEシャント造設後 1 年以内に死亡し, TEシャ ントが意義ある使用となっていなかった可能性のある症例 は 5 例, 約 $10 \%$ にもび, 全体の半数は, TEシャント発 声を有意義に使用できたか疑問に思われる症例であった。

\section{2 ) 原発巣治療の背景因子}

対象症例 9 例の原発巣治療の背景因子を表 1 に示した。 原発部位・亜部位に関しては，喉頭癌症例は，声門癌症例 はなく, 声門下癌一例を除いてすべて声門上癌であった。 再発治療例は 2 例のみで, これらは一次治療時の化学放射 線治療で十分な根治線量と同時併用の抗がん剂が投与され ていた。喉頭癌の一次治療例 6 例中 2 例では, CBDCA 同 時併用化学放射線治療 $40 \mathrm{~Gy}$ 施行され，治療効果が見られ ないため，喉頭全摘術を施行された症例であった。さらに 術後照射を行った症例は 3 例あった．9例は全例，喉頭全 摘術後 6 年以上の経過観察期間があり，他病死 3 例以外は いずれも無病生存例であり, 原病の制御は十分な症例で あった。

\section{3）シャント閉鎖術の背景因子}

手術時間, 対象症例 9 例のシャント閉鎖術の背景因子を 表 2 に示した。 TEシャントは 1 例を除いて，全例一期的 造設術を行っていた，閉鎖に至った理由は，シャント孔か らの食物や唾液のリークによる嚥下性肺炎を合併し，根治 のために閉鎖を余儀なくされたものと，食道発声が可能と なったためTEシャントが不必要となったものが, 全くの 同数で, 全体をほぼ 2 分した. シャント閉鎖までの期間は, $2 \sim 3$ 年程度の症例が 6 例， 7 年を超えた長期の症例が，3 例であった，閉鎖術式でみると，閉鎖までの期間が $2 \sim 3$ 年程度の症例は，比較的侵襲の低い，術式(1)，(2)で，1回 目の手術で閉鎖したのに対し，7年を超えた長期の症例で は，複数回の手術の後，侵襲の高い術式(3)で漸く閉鎖でき た。閉鎖術まで194ケ月の症例 1 は，術式(3)を行う予定と したが，呼吸機能などの問題で全身麻酔手術が不可能と判 断され，閉鎖ができずに現在に至っている.

\section{考察}

TEシャントは, 獲得率・習得までの期間, 音質, 最長 発声持続時間 (MPT), などに関して代替音声の中で最も 優れたモダリティと考えられている。音声獲得率について は，食道発声が扔よそ半数程度の獲得率である ${ }^{1,2,8)}$ のに 対し，TEシャントは $90 \%$ を超えるとする報告が多い ${ }^{1 \sim 6)}$. 習得に要する期間は，食道発声では，2 ケ月以内で単音節 発声を習得出来た症例が $60 \%$ 程度にとどまるの ${ }^{8,9)}$ に対し て, TEシャントは特別な訓練もなく発声可能となり, 直 後から短い会話であれば可能となる症例も多く存在する. 音質については, 電気式人工喉頭の単調な機械的音声と比 較し，より自然な音声と感じられる，MPTについても，食 道発声では平均 2.3 秒とする報告がある ${ }^{10)}$ 一方，気管食道
シャントでは平均で 12 秒を超える報告が多い ${ }^{1,11 \sim 14) 。 こ ~}$ のような優れた結果から，TEシャントは代替音声の “GOLD STANDARD”と評されている7).

一方, Querら ${ }^{15)}$ は, TEシャント, 食道発声の両者を 使用可能な症例においては, 食道発声の有用性が高く, $70 \%$ の症例でTEシャントを閉鎖したと報告している。ま た，以前，報告した自験例の検討 ${ }^{16)}$ おいても，TEシャン 卜症例の $67 \%$ しか，実際の会話に使用されておらず，思 いの外利用されていない実態が明らかになっている，本検 討で脱落閉鎖後に再度挿入していなかった症例数の多いこ とが示されたが，再挿入しなかった全例で，コミュニケー ション ッールとしてTEシャントは必要ではないと明確 な意思表示があった。これらを考虑すると, 個々のTE シャントの必要性を考慮せず，単純喉頭全摘術症例は原則 的にTEシャントを造設したことが, 当科での低い TEシャ ント利用割合の原因の一つと考え反省している.

これを受けて，長期に渡り使用される代替音声をどのよ うなプロセスを経て獲得するかが，重要なテーマであると 考えている．特に有効性の高いTEシャントをより効率よ く使用してもらうため, どの様な症例を適応とするか吟味 することが必要であると考えた。本研究では，その一助と してTEシャント閉鎖術を施行した症例の概要を検討し た。

本検討では，TEシャントを閉鎖する症例の半数は，食 道発声が可能となったことがその理由となっていた。ま た，TEシャントが必要でなくなった場合，TEシャント造 設後 3 年程度であれば，大きな侵襲なくシャント閉鎖が可 能であろうことが推測できた。これらのことから, TEシャ ントを喉頭摘出術後速やかに造設するが, 喉頭摘出後 3 年 間はしっかり食道発声のトレーニングを行い, 発声可能と なれば患者の希望に応じて速やかにTEシャントを閉鎖す ることが，代替音声獲得プロセスの一つの選択枝として提 案できると考えられた。一方で, 安易に習得が容易な TE シャントを针めると, 食道発声をなかなか獲得できない, または，食道発声を習得する意思がなくなってしまう可能 性もある。実際, 食道発声の習得を勧めても, トレーニン グを前向きに行う症例は少ない印象であった。これらを考 えると，TEシャントは一期的に造設せず，一定期間食道 発声をしっかりトレーニングし, 習得し得ない症例に対し てTEシャントを造設するほうが，より良いとも考えられ る. 現在，当科ではこの方針で実際行っているが，今後ど ちらの選択枝を取るべきか，これまでの当科の実績や本検 討の結果を十分患者に説明した上で，患者の判断を仰ぐこ とにしたい

今回の検討で，TEシャント管理の課題としてあげられ たのは，TEシャントをより長期間有効に使用した結果と してシャント孔が拡大し, シャント孔より食物・唾液の リークが出現した場合の対応である。本検討でシャント孔 からのリークが原因で與下性肺を合併しシャント孔を閉鎖 した 4 症例は，いずれも頸部の照射後症例で，うち 3 例は 
7 年以上の長期の TE シャント使用症例であった．経年的 なシャント孔周囲の阻血や痏痕化が高度となり, 恒久的な シャント孔拡大となって, 気道へのリークが遷延し肺炎を 来していたが，これらの症例ではシャント孔閉鎖の際に は，侵襲の高い閉鎖手術術式が必要となっており，シャン 卜孔周囲の組織変化が，取りも直さず閉鎖手術の困難さの 原因となっていた，現在トラブルなく使用している症例に おいても，長期使用例においては，今後このようなシャン トトラブルが増加する可能性は否定できない，長期使用 ユーザーへのサービスの一環として, シャント孔拡大に対 応できるような, プロステーシス口径に幾つかのラインナッ プを揃えるメーカー側の企業努力も必要であると考える.

$$
\text { ま と め }
$$

1. 当科で単純喉頭摘出術後に気管食道シャントを造設し た症例で，シャント閉鎖手術を施行した 9 例を対象に, 症例の背景，閉鎖に至った理由，シャント閉鎖の術式 を検討した。

2. シャント閉鎖に至った理由は, シャント孔からのリー クによる嚥下性肺炎の併発と, 食道発声が可能となり シャント発声を必要としなくなったことが多かった。

3. 造設後 7 年以上を経過した症例で，シャントを閉鎖す る場合，大胸筋弁，DP皮弁などの血流の豊富な組織を 付加する必要があった。

4. 造設後 3 年程度までに食道発声を獲得するならば, 比 較的簡便にシャント孔を閉鎖することが可能であると 考えられた。

利益の相反に該当する事項はない.

\section{文献}

1）上前泊 功, 芦澤 圭, 中山雅博ほか：喉頭摘出後の 気管食道シャント発声者と食道発声者に掞ける QOL 評価 - Voice Handicap Index (VHI) 日本語改定版抒 よびVoice-Related Quality of Life (V-RQOL) 日本語 版を用いて一。耳鼻臨床１06:1033-1038, 2013.

2) van Weissenbruch R, Albers FW : Voice rehabilitation after total laryngectomy. Acta Otorhinolaryngol Belg 46 : 221-246, 1992.

3) Op de Coul BM, Hilgers FJ, Blam AJ et al : A decade of postlaryngectomy vocal rehabilitation in $318 \mathrm{pa}-$ tients: a single institution's experience with consistent application of provox indwelling voice prostheses. Arch Otolaryngol Head Neck Surg 126 : 1320-1328, 2000.

4）福島啓文：シャント発声のリハビリテーション。耳喉 頭頸 $85: 326-332,2013$.
5) Chone CT, Gripp FM, Spina AL et al : Primary versus secondary tracheoesophageal puncture for speech rehabilitation in total laryngectomy : long-term results with indwelling voice prosthesis. Otolaryngol Head Neck Surg 133 : 89-93, 2005.

6) Kao WW, Mohr RM, Kimmel CA et al : The outcome and techniques of primary and secondary tracheoesophageal puncture. Arch Otolaryngol Head Neck Surg 120:301-307, 1994.

7) Lewin JS, Hutcheson KA : General principles of rehabilitation of speech, voice, and swallowing function after treatment of head and neck cancer. Head and neck cancer : a multidisciplinary approach, (Harrison LB, Sessions RB, Hong WK ed), 168-177, Lippincott Williams \& Wilkins, Philadelphia, 2009.

8）藤井 隆, 佐藤武男, 吉野邦俊ほか：喉摘者の音声リ ハビリテーション，とくに食道発声習得について。 日 耳鼻 $96:$ 1086-1093, 1993.

9）前田秀彦, 西澤典子, 玉重詠子：喉頭摘出後の食道音 声使用者に対する実態調査 一北海道喉頭摘出者団体 へのアンケート調査一。音声言語医学 $55: 226$-232, 2014.

$10 ）$ 尾原恵美, 伊藤元信, 菊地義信 : 食道発声における発 話明瞭度 一明暸度低下の要因について一。音声言語 医学 $47: 5-15,2006$.

11) Robbins J, Fisher HB, Singer MI : A comparative acoustic study of normal, esophageal, and tracheoesophageal speech production. J Speech Hear Disord $49: 202-210,1984$.

12) Pindzola RH, Cain BH : Duration and frequency characteristics of tracheoesophageal speech. Ann Otol Rhinol Laryngol 98: 906-914, 1989.

13）小島卓朗, 加藤一郎, 中田誠一ほか：Voice prosthesis を用いた気管食道シャント手術による術後音声機能獲 得に関する検討。音声言語医学 $55: 215$-218, 2014.

14) 大月直樹, 斎藤 幹, 丹生健一：喉頭全摘後の音声機 能評価. 喉頭 $19: 80-82,2007$.

15) Quer M, Burgués-Vila J, García-Crespillo P : Primary tracheoesophageal puncture vs esophageal speech. Arch Otolaryngol Head Neck Surg 118: 188-190, 1992.

16）那須 隆，小池修治，野田大介ほか：Voice prosthesis による喉頭摘出後の音声リハビリテーション 長期経 過と合併症の検討。日気食会報 $60: 16-22,2009$.

別刷請求先 $=990-9585$ 山形市飯田西 2-2-2 山形大学医学部耳鼻咽喉科那須 隆 